\title{
Biological Methodologies on SDHI Fungicides to Assess Reductions of Sensitivity and Activity on Venturia inaequalis and Cross-Resistance Tests
}

\author{
R. Fiaccadori, G. Battistini \\ Department of Agricultural and Food Sciences (DISTAL) University of Bologna, Bologna, Italy \\ Email: riccardo.fiaccadori@unibo.it
}

How to cite this paper: Fiaccadori, R. and Battistini, G. (2021) Biological Methodologies on SDHI Fungicides to Assess Reductions of Sensitivity and Activity on Venturia inaequalis and Cross-Resistance Tests. American Journal of Plant Sciences, 12, 1124-1134.

https://doi.org/10.4236/ajps.2021.127078

Received: June 8, 2021

Accepted: July 26, 2021

Published: July 29, 2021

Copyright $\odot 2021$ by author(s) and Scientific Research Publishing Inc. This work is licensed under the Creative Commons Attribution International License (CC BY 4.0).

http://creativecommons.org/licenses/by/4.0/

(c) (i) Open Access

\begin{abstract}
Biological methodologies (in vitro and in vivo) were tested on Venturia inaequalis to assay sensitivity of populations treated with the SDHI penthiopyrad, fluxapyroxad and fluopyram that showed a field poor control in an experimental Centre. In comparison, sensible populations were tested. In vitro trials, the poorly controlled populations presented moderate increases of $\mathrm{EC}_{50}$ and $\mathrm{RF}$ values in all three years in which tests were carried out. The in vivo trials in glasshouse showed that the activity of SDHI fungicides on field poorly controlled populations was highly reduced. These populations can be defined as "resistant" as the high loss of sensitivity and activity were repeatedly assessed in field and glasshouse. Trials showed that these reductions were manifested by curative applications and not by preventive ones, as already ascertained for $V$. inaequalis populations resistant to AP and DMI fungicides. The cross-resistance of resistant populations to the three SDHIs was highly positive among them. In bibliography, there are only researches of cross-resistance among SDHIs starting from isolates resistant to boscalid, with results of different sensitivities and cross-resistance. These results with populations of $V$. inaequalis resistant to the three SDHI offer practical evaluations in cross-resistance.
\end{abstract}

\section{Keywords}

Venturia inaequalis, SDHI, Fungicides, Scab Control, Sensitivity, Methodology

\section{Introduction}

Venturia inaequalis (Cke.) Wint., commonly named apple scab, has been the main adversity of apples in Italy and in many other Countries, with more than 
10 treatments [1] and a diffusion in over 62 Countries around the world [2].

So it is very important to count on several fungicides with different mechanism of action. The recent group of SDHI fungicides (Succinate Dehydrogenase Inhibitors) has an important role in apple scab control, as well as many other diseases. These fungicides have a monosite mechanism of action: enzyme of succinate-dehydrogenases, SDH, in complex II of mithocondrial respiratory chain.

The first SDHI distributed were carbossina and flutolanil that evidenced an activity limited to Basidiomycetes, regarding only seedlings and ground [3].

Since 2003 a new SDHI, named boscalid, was commercialized and had activity on many fungi of epigean part of several crops. The use was generally authorized towards Botrytis spp. of grapevines, strawberry and kiwi, the Alternaria spp. of potato, pistachio, kiwi, Oidium spp. of Cucurbitacee and towards several diseases of cereals. In Italy and other Countries boscalid was advised and commercialized for apple scab only in mixture with pyraclostrobin.

About resistance risk, this chemical group is monosite, so have a medium-high risk of resistance. Moreover, researches detected that the mutations, in complex II, were possible and could happen in many points, at least 43 . However, these mutations cause levels of sensitivity reduction very different, from very low to very high, depending on the specific mutation and the pathogen [4].

The boscalid was introduced with resistance recommendations, regarding especially the number of treatments on each crop, from two to four, depending on the total number of fungicide applications [5]. However, resistance was detected with referring to boscalid since 2010, both in laboratory on mutants of Botritis spp. of strawberry [6] and in the field, on Alternaria of kiwi [7], potato [8], and towards Corynespora cassiicola of cucumber [9]. In Italy field resistant monoconidia of $V$. inaequalis were detected [10].

In last years, at least 20 new fungicides of SDHI group were marketed and in Italy, versus apple scab, were introduced fluxapyroxad (commercial name Sercadis), penthiopyrad (Fontelis) and fluopyram (Luna Privilege).

These SDHIs had a high interest in $V$. inaequalis because showed a good preventive (most utilized) and also curative activity [11] [12]. They have action both on leaves and fruits and do not present fitotoxicity. The activity is confirmed by field trials [13] in Po river valley that has high humidity and moderate temperatures, favoring severity of apple scab. The importance of these new SDHI has increased in all over the world, because the most active fungicides used against apple scab presented moderate or heavy resistance problems, as dodina [14], strobilurins, anilino-pyrimidines [15] and the most used demethylation inhibitor (difenoconazole) [16] and their use must be limited.

These new SDHI's present, until now, no reports of reduced sensitivity or suspects of field resistance, but only remarks about the presence of resistant isolates in the field, especially on Botrytis of strawberry [17]. With referring to $V$. inaequalis, two mutations were detected on isolates that can cause reduction of sensitivity [18], but actually, there are no problems of field resistance, also thanks to Plant Protection Services that insist on anti-resistance recommenda- 
tions.

The studies on cross-resistance were generally realized starting from isolates resistant to boscalid and extended to new SDHIs and were very complex for the high number of possible mutations and consequently a different behavior in sensitivity and cross-resistance [5] [8].

This work has the aim to study biological methodologies to assay the loss of sensitivity and activity of these SDHIs employed on $V$. inaequalis, and to verify the cross-resistance among these populations.

\section{Materials and Methods}

In vitro and in vivo assays were carried out on samples of $V$. inaequalis populations belonging to three types:

- "Sensible wild-type": population located in non-agricultural and not treated zones.

- "Sensible baseline": treated populations in commercial orchards, already tested as sensible to the main fungicides for apple scab and collected before introduction of SDHIs.

- "Poorly controlled" field populations coming from an experimental orchard (Altedo, Province of Bologna) in which penthiopyrad, fluopyram e fluxapyroxad were applied intensively, causing a consistent presence of Venturia inaequalis infections. Considered years were 2014, 2015 and 2016.

The populations tested and their locations are presented in the tables.

In preparation of inoculum, scabbed leaves from orchards belonging to the three types were withdraw and sent to laboratory where $30-40$ scabbed leaves were chosen. Conidia in spots were collected, by suction with sterile water, and inoculated on apple seedlings, as drops, to obtain a more consistent and vital inoculum for in vitro and in vivo tests.

\subsection{In Vitro Tests}

After preliminary assays, the adopted methodology was similar to that fine-tuned for sensitivity to strobilurins [15] and the only difference was one higher concentration. From multiplied scabbed leaves, a quantity of material (about $0.14 \mathrm{~g}$ ) was withdrawn and put in $2 \mathrm{ml}$ of sterile water, to obtain a concentration of 1 - 2 $\times 10^{5}$ conidia $/ \mathrm{ml}$. From this dispersion, rates of $20 \mu \mathrm{l}$ were aspirated with automatic pipet and put as drops on agarized Petri dishes (AGAR GRADE A, DIFCO, Detroit, USA), in which each SDHI fungicide (penthiopyrad, fluopyroxad and fluxapyram) was previously dissolved. The fungicides were used as technical active material (PESTANAL, SIGMA-ALDRICH, Saint Louis, USA) with different concentrations (mg/l): 0.0,0.001, 0.01, 0.1, 1 and 10. Streptomycin sulfate was added and dissolved in agar (FLUKA-HONEYWELL, Morristow, USA) with concentration of $200 \mathrm{mg} / \mathrm{l}$.

For every population and concentration, two drops (each one for replication) were put in Petri dishes and successively placed in thermostat at $20^{\circ} \mathrm{C}$ for 24 
hours with 12 hours of photoperiod. At the end, the count of conidia (150 for each replication) was realized to assay percentage of germinated ones. The relative efficiency (\%) was processed with probits (program made with excel by a colleague and a programmer), to obtain the $\mathrm{EC}_{50}$ (concentration that reduces the germination of test by 50\%) and the FR (Resistance Factor as ratio between $\mathrm{EC}_{50}$ of each treated sample and the test-baseline).

Two tests were realized on every population, each one utilizing a different subpopulation. About poorly controlled populations of sperimental Centre, sensitivity, test were carried out in 2014, 2015 and 2016. The results were compared with the $\mathrm{EC}_{50}$ mean value of seven sensible and baseline populations tested on the three SDHIs and on a standard fungicide.

\subsection{In Vivo Tests}

Seedlings of apple cv Golden were grown in glasshouse with substrate: 1/3 turf, $1 / 3$ sand and $1 / 3$ humus. The $V$. inaequalis populations of the three types were inoculated on these seedlings, in number of 5 or 6 for each type of treatment, at the stage of 5 - 6 leaves, spraying about $1.2 \mathrm{ml} /$ plant of a conidia suspension, and concentrated $1-2 \times 10^{5} / \mathrm{ml}$.

Inoculations were made in climatic cells in which seedling were maintained wet in closed and darken containers for 48 hours at about $20^{\circ} \mathrm{C}$. Incubation was performed at the same temperature, with a daily humidity range from $50 \%$ to $90 \%$ and the average natural light was 34 PAR (photosynthetically active radiation). The assessment of infection was realized $21-22$ days after inoculation, detecting the percentage of scabbed leaf area and the relative efficacy $(\%)^{*}$.

Every test included populations poorly controlled of sperimental Centre, collected in 2015, comparing with sensible ones, represented by treated baselines and one wild type. Each poorly controlled population was treated preventively or curatively with the same SDHI utilized in the field, together with a standard fungicide. The sensible ones were treated with the same fungicides. It was difenoconazole in curative applications and captan in preventive ones.

The fungicides tested, applied doses and ways of application are indicated in Table 1.

Curative treatments were applied 52 - 54 hours after the beginning of infection, while preventive ones were anticipated $70-72$ hours. Two tests were realized for every population and type of treatment, utilizing different subpopulations. Wild-type population was tested one time on every population, to help preservation of the characteristics of these strains.

$$
\begin{aligned}
& \text { relative efficacy } \% \\
& =\frac{\text { degree of infection of test }- \text { degree of infection treated sample }}{\text { degree of infection of test }} \times 100
\end{aligned}
$$

\subsection{Cross-Resistance Tests}

Each of the poorly controlled population was curatively or preventively treated with each SDHI. These were applied at the same number of hours previously indicated. 
Table 1. Fungicides: trade names, doses, active materials and times of preventive and curative applications.

\begin{tabular}{|c|c|c|c|c|c|c|}
\hline \multicolumn{2}{|c|}{ Commercial product } & \multicolumn{3}{|c|}{ Active material } & \multirow{2}{*}{$\begin{array}{l}\text { Preventive } \\
\text { treatment: } \\
\text { hours } \\
\text { before } \\
\text { inoculum }\end{array}$} & \multirow{2}{*}{$\begin{array}{l}\text { Curative } \\
\text { treatment: } \\
\text { hours post } \\
\text { inoculum }\end{array}$} \\
\hline Trade name & $\begin{array}{c}\text { Dose } \\
\mathrm{g} / \mathrm{L}\end{array}$ & Name & $\%$ a.m. & $\begin{array}{c}\text { Dose } \\
\mathrm{g} / \mathrm{L}\end{array}$ & & \\
\hline Fontelis & 0.74 & penthiopyrad & 20.44 & 0.15 & $70-72$ & $52-54$ \\
\hline Sercadis & 0.20 & fluxapyroxad & 26.50 & 0.05 & $70-72$ & $52-54$ \\
\hline $\begin{array}{c}\text { Luna } \\
\text { Privilege }\end{array}$ & 0.24 & fluopyram & 41.66 & 0.09 & $70-72$ & $52-54$ \\
\hline Score $25 \mathrm{EC}$ & 0.16 & difenoconazole & 23.23 & 0.03 & & $52-54$ \\
\hline $\begin{array}{c}\text { MakeUp } \\
\text { 480SC }\end{array}$ & 3.70 & captan & 39.30 & 1.45 & $70-72$ & \\
\hline
\end{tabular}

In each test were present also sensible populations and a standard fungicide, differentiated for preventive and curative applications, as above mentioned.

This research was realized with in vivo tests. Every population was tested with two replications, utilizing different subpopulations. The populations of the sperimental Centre used were those of 2015, already used for in vivo tests.

\section{Results}

- In vitro: in Table 2 there are results of populations intensively treated with penthiopyrad, fluopyram e fluxapyroxad in experimental Centre, compared with a mix of sensible populations (baseline).

The used parameters: $\mathrm{EC}_{50}$ and FR showed that the reductions of sensitivity of poorly controlled populations of experimental Centre were moderate respect the considered mix of sensible populations. This can be detected for all the three SDHI and in all the considered years: 2014, 2015 and 2016. The maximum value of $\mathrm{EC}_{50}$ was 0.12 for penthiopyrad, 0.16 for fluxapyroxad and 0.17 for fluopyram. In addition, the parameter FR showed continents values, from 2.9 to 4.3 for penthiopyrad, from 6.5 to 8.8 for fluxapyrosad and from 4.0 to 4.1 for fluopyram.

- In vivo: as in vitro, trials on field populations poorly controlled were realized and compared to sensible ones (treated baselines and one wild-type).

In preventive treatments (Table 3), poorly controlled populations showed an activity (relative efficacy \%) between 85.0 and 97.4 in treatments with penthiopyrad, fluxapyroxad or fluopyram. More than $97.0 \%$ was the activity of standard fungicide (captan) on these populations. Superior to $97.9 \%$ was the preventive activity of the three SDHIs related to the three sensible populations.

The activity of the SDHIs and of captan on wild-type population was complete (100\%).

In curative treatments (Table 4), the populations poorly controlled by SDHI, showed the same situation in glasshouse, with relative efficacies from 3.8 to $7.8 \%$. 
Table 2. Results of in vitro tests on sensitivity to the three SDHI by sensible (baseline) and poorly controlled $V$. inaequalis populations.

\begin{tabular}{lccc}
\hline Treatments and location of populations: & Year & $\begin{array}{c}\mathrm{EC}_{50} \\
(\mathrm{mg} / \mathrm{L})\end{array}$ & $\begin{array}{c}\text { FR (Resistance } \\
\text { Factor) }\end{array}$ \\
\hline $\begin{array}{l}\text { Penthiopyrad (poorly controlled). } \\
\text { Sperimental Centre, Altedo (Bologna, }\end{array}$ & 2014 & 0.120 & 2.9 \\
Emilia-Romagna) & 2015 & 0.101 & 4.8 \\
Baseline & & 0.091 & 4.3 \\
\hline Fluxapyroxad (poorly controlled) & 2014 & 0.021 & 6.5 \\
SperimentalCentre, Altedo (Bologna, & 2015 & 0.118 & 6.6 \\
Emilia-Romagna) & 2016 & 0.120 & 8.8 \\
Baseline & & 0.160 & \\
\hline $\begin{array}{l}\text { Fluopyram (poorly controlled) } \\
\text { Sperimental Centre, Altedo (Bologna, }\end{array}$ & 2014 & 0.018 & 4.1 \\
Emilia-Romagna) $^{*}$ & 2015 & 0.170 & 4.0 \\
Baseline & 2016 & 0.165 & \\
\hline
\end{tabular}

${ }^{*}$ mean of $\mathrm{EC}_{50}$ values of 7 samples from different locations and Regions (or Provincies): n.98 Cona (Ferrara, Emilia-Romagna); n.116 Teglio (Sondrio, Lombardia); n.118 Pordenone (Friuli); n.132 S.Giorgio (Pordenone, Friuli); n.156 (Forli, Emilia-Romagna); n.234 Trento; "misto": a mix of 14 sensible populations coming from Emilia-Romagna, Lombardia, Friuli Regions and Trentino Province. ${ }^{\star \star}$ not detected.

Table 3. Preventive activity in glasshouse of SDHI fungicides on "poorly controlled" and sensible $V$. inaequalis populations.

\begin{tabular}{|c|c|c|c|c|c|}
\hline \multirow{2}{*}{$\begin{array}{c}\text { Treatments and } \\
\text { management of } \\
\text { populations: }\end{array}$} & \multirow{2}{*}{ Location } & \multicolumn{4}{|c|}{$\begin{array}{c}\text { Relative efficacy (\%) of the three SDHIs } \\
\text { and standard fungicide }\end{array}$} \\
\hline & & Penthiopyrad & Fluopyram & Fluxa-pyroxad & Captan \\
\hline $\begin{array}{l}\text { Penthiopyrad } \\
\text { (poorly } \\
\text { controlledl) }\end{array}$ & $\begin{array}{l}\text { Sperimental Centre } \\
\text { (Altedo, Bologna) }\end{array}$ & 97.4 & & & 98.2 \\
\hline $\begin{array}{l}\text { Fluopyram } \\
\text { (poorly } \\
\text { controlled) }\end{array}$ & $\begin{array}{l}\text { Sperimental Centre } \\
\text { (Altedo, Bologna) }\end{array}$ & & 95.8 & & 100 \\
\hline $\begin{array}{l}\text { Fluxapyroxad } \\
\text { (poorly } \\
\text { controlled) }\end{array}$ & $\begin{array}{l}\text { Sperimental Centre } \\
\text { (Altedo, Bologna) }\end{array}$ & & & 85.0 & 97.1 \\
\hline Sensible n.156 & Forlì Emilia-Romagna & 97.9 & 100 & 98.6 & 95.8 \\
\hline Sensible "mixed" & $\begin{array}{l}\text { A mixture of } 14 \\
\text { populations coming } \\
\text { from } \\
\text { Emilia-Romagna, } \\
\text { Lombardia, Friuli } \\
\text { Regions and } \\
\text { Trentino Province }\end{array}$ & 99.5 & 100 & 100 & 100 \\
\hline $\begin{array}{l}\text { Sensible } \\
\text { wild-type }\end{array}$ & $\begin{array}{l}\text { Foodplain of Po river, } \\
\text { Suzzara (Lombardia) }\end{array}$ & 100 & 100 & 100 & 100 \\
\hline
\end{tabular}


On these populations the difenoconazole showed a relative efficiency moderately high.

The sensible populations (baseline) allowed the SDHIs to show a curative activity from $78.4 \%$ to $98.4 \%$, while on the wild-type it was higher, with degrees of action always superior to $96.7 \%$. Difenoconazole showed on all these sensible populations a curative activity always superior to $96.7 \%$.

In tests of cross-resistance (Table 5), the examine of preventive treatments displayed that the populations field treated with fluxapyrosad, penthiopyrad or fluopyram in sperimental Centre, were well controlled by the same SDHI utilized in field and also by the other two fungicides. The relative efficacy (\%) was always superior to 78.7. Near to 100 was always activity showed by captan on these populations.

On sensible populations (baselines and wild-type), the activity of SDHI was confirmed very high, with a relative efficacy (\%) always superior to 97.9. On these populations the activity of captan ranged from 95.8 to 100 .

On the contrary, curative applications presented very low levels of control by each SDHI, both on population field treated with the same fungicide and with the else populations treated with the other SDHIs. All the relative efficacies (percentage) range from 0.0 to 16.7 .

Table 4. Curative activity in glasshouse of SDHI fungicides on "poorly controlled" and sensible $V$. inaequalis populations.

\begin{tabular}{|c|c|c|c|c|c|}
\hline \multirow{2}{*}{$\begin{array}{c}\text { Treatments and } \\
\text { management of } \\
\text { populations: }\end{array}$} & \multirow{2}{*}{ Location } & \multicolumn{4}{|c|}{$\begin{array}{c}\text { Relative efficacy (\%) of the three SDHIs } \\
\text { and standard fungicide }\end{array}$} \\
\hline & & Penthiopyrad & Fluopyram & Fluxa-pyroxad & Difenoconaz. \\
\hline $\begin{array}{l}\text { Penthiopyrad } \\
\text { (poorly } \\
\text { controlledl) }\end{array}$ & $\begin{array}{l}\text { Sperimental Centre } \\
\text { (Altedo, Bologna) }\end{array}$ & 7.8 & & & 49.5 \\
\hline $\begin{array}{l}\text { Fluopyram } \\
\text { (poorly } \\
\text { controlled) }\end{array}$ & $\begin{array}{l}\text { Sperimental Centre } \\
\text { (Altedo, Bologna) }\end{array}$ & & 5.7 & & 39.1 \\
\hline $\begin{array}{l}\text { Fluxapyroxad } \\
\text { (poorly } \\
\text { controlled) }\end{array}$ & $\begin{array}{l}\text { Sperimental Centre } \\
\text { (Altedo, Bologna) }\end{array}$ & & & 3.8 & 49.8 \\
\hline Sensible n.156 & $\begin{array}{l}\text { Forlì } \\
\text { Emilia-Romagna }\end{array}$ & 78.4 & 76.4 & 79.2 & 99.7 \\
\hline Sensible "mixed" & $\begin{array}{l}\text { A mixture of } 14 \\
\text { populations } \\
\text { coming from } \\
\text { Emilia-Romagna, } \\
\text { Lombardia, Friuli } \\
\text { Regions and } \\
\text { Trentino Province }\end{array}$ & 91.5 & 98.4 & 85.0 & 96.8 \\
\hline $\begin{array}{l}\text { Sensible } \\
\text { wild-type }\end{array}$ & $\begin{array}{l}\text { Foodplain of Po } \\
\text { river, (Suzzara, } \\
\text { Lombardia) }\end{array}$ & 98.8 & 98.6 & 99.4 & 100 \\
\hline
\end{tabular}


Table 5. In vivo results of cross-resistance to each of the SDHI fungicides of $V$. inaequalis resistant populations, with preventive or curative applications. A standard fungicide was present as comparison.

(a)

\begin{tabular}{ccccc}
\hline & \multicolumn{4}{c}{ Preventive applications } \\
\cline { 2 - 5 } Populations tested $^{*}$ & \multicolumn{4}{c}{ Relative efficacy (\%) on population treated with: } \\
\cline { 2 - 5 } & Penthiopyrad & Fluxapyroxad & Fluopyram & Captan \\
\hline Penthiopyrad resistant & 97.9 & 88.0 & 98.4 & 98.2 \\
Fluxapyroxad resistant & 84.9 & 78.7 & 88.0 & 97.1 \\
Fluopyram resistant & 95.8 & 87.7 & 95.8 & 100 \\
Sensible n.156 & 97.9 & 98.6 & 100 & 95.8 \\
Sensible "mixed" & 99.5 & 100 & 100 & 100 \\
Sensible "wild-type" & 98.6 & 100 & 99.3 & 100 \\
\hline
\end{tabular}

${ }^{\star}$ Location of samples in Table 3 or Table 4.

(b)

\begin{tabular}{ccccc}
\hline & \multicolumn{4}{c}{ Curative applications } \\
\cline { 2 - 5 } Populations tested* & \multicolumn{3}{c}{ Relative efficacy (\%) on population treated with: } \\
\cline { 2 - 4 } & Penthiopyrad & Fluxapyroxad & Fluopyram & Difenoconazole \\
\hline Penthiopyrad resistant & 10,0 & 15.5 & 5.7 & 39.1 \\
Fluxapyroxad resistant & 7.8 & 0.0 & 8.9 & 50.2 \\
Fluopyram resistant & 11.5 & 3.8 & 16.7 & 46.1 \\
Sensible n.156 & 87.8 & 90.9 & 89.2 & 97.5 \\
Sensible "mixed" & 89.1 & 73.5 & 100 & 94.8 \\
Sensible “wild-type" & 98.8 & 99.4 & 98.6 & 100 \\
\hline
\end{tabular}

${ }^{\star}$ Location of samples in Table 3 or Table 4.

Difenoconazole presented medium activity values on populations resistant to the three SDHIs.

In comparison with the two baselines and the wild type, the activity results of the SDHI were higher, near the complete protection and similar to that of difenoconazole.

\section{Discussion}

In vitro trials, the $V$. inaequalis populations, poorly controlled by SDHIs, showed $\mathrm{EC}_{50}$ values moderately reduced, never superior to $0.17 \mathrm{mg} / \mathrm{l}$ and $\mathrm{RF}$ never higher than 10. This result appears rather strange, as they are monosite fungicides that should present, in our situation, high reductions of sensitivity, similar to strobilurins. However, these results are confirmed by three years of field trials.

From bibliography, tests realized with isolates and not with populations resistant to SDHI (generally boscalid) show lower sensitivities: those highly resistant have $\mathrm{EC}_{50}$ values superior to $100 \mathrm{mg} / \mathrm{l}$, while the others moderately resistant have $\mathrm{EC}_{50}$ values with a range between 5 and $20 \mathrm{mg} / \mathrm{l}$ [6] [9] on other pathogens but 
must be pointed out that these tests were realized starting from isolates resistant to boscalid.

On the contrary the in vivo trials showed that the activity of SDHIs on field poorly controlled populations was very low and remarkably inferior to the sensible ones. However this situation was detected only with curative treatment (52 54 hours), while the reduction was very light or not present in preventive one (70 - 72 hours). With the last type of treatment, the poorly controlled populations confirmed the high activity of penthiopyrad and fluopyram, similar to captan, while fluxapyroxad showed lightly inferior performances.

On sensible populations, SDHI's confirmed a very good activity on sensible populations in preventive treatments, similar to captan, while it can be considered high but moderately inferior to difenoconazole in that curative.

These populations with "reduced control" can be considered as "field or practically resistant" to the three SDHI, also in absence of detection of genetic mutations. Indeed the characteristics of highly reduced sensitivity and activity were confirmed for several years, both in field and in vivo on conidia repeatedly inoculated in glasshouse.

The difenoconazole showed only a moderate activity on resistant populations, comparable to a partial cross-resistance. This behaviour appears strange because the SDHIs and difenoconazole present different sites and modes of action. On the contrary, captan showed a normal behavior with very high activity in preventive applications.

The populations resistant to SDHIs confirmed what was already observed on those resistant to DMIs [16] and to APs pyrimethanil and cyprodinil [19], as they show reductions of sensitivity and activity only with curative applications, while present light or no reductions in preventive ones.

The researches on cross-resistance showed that it was clear and positive among populations resistant to penthiopyrad, fluxapyroxad and fluopyram and it was visible only with the curative application. The elevated activity of SDHI in preventive treatment caused the impossibility to make differences among resistant populations in cross-resistance.

In bibliography there are reports of cross resistance referred only to isolates of several pathogens clearly resistant to boscalid that were tested on other SDHI. These results showed a positive cross-resistance, but with different intensities from high to low [5] [8]. The motive is probably owing to the fact that isolates resistant to SDHIs, in complex II of mithocontrial respiratory chain, present many mutations, with different levels of sensitivity [4].

Must be pointed out that these different sensitivities were referred to isolates, so it is very difficult to correlate these results to the sensitivity of each population. The evaluation of cross-resistance using population is less scientifically precise respect isolates or monoconidia, but is more practical.

\section{Acknowledgements}

I thank Prof. Agostino Brunelli of University of Bologna for samples from his 
sperimental Centre, Prof. Marina Collina (Bologna University) for logistic support, Phytopathological Service of Emilia-Romagna for sensible samples, Giulia Toschi for glasshouse work and Angela Finestrelli for help in trials execution.

\section{Conflicts of Interest}

The author declares no conflicts of interest regarding the publication of this paper.

\section{Financed}

Studies financed from Emilia-Romagna Region as part of PSR 2014-2020 Op 16.1.01 GO PEI-Agri-FA 48, Pr. "Resistances" with coordination of CRPV.

\section{References}

[1] Casagrandi, M. and Marzocchi, L. (2008) Copertura completa del meleto nei trattamenti antiticchiolatura. Terra e Vita, 14, 76-79.

[2] MacHardy, W. (1996). Apple Scab Biology, Epidemiology and Management. APS Press, Minnesota, 2-3.

[3] Bencivelli, A., Bernardi, G., Fabiani, G., Massasso, W. and Turchiarelli, W. (1986) Moncut $^{\oplus}$ (Flutolanil): Nuovo fungicida sistemico-scheda tecnica e risultati di quattro anni di prove contro Rhizoctonia Solani su garofano. Atti Giornate Fitopatologiche, II, 465-470.

[4] FRAC (2015)

https://www.frac.info/docs/default-source/working-groups/sdhi-references/list-of-s pecies-resistant-to-sdhis-april-2015.pdf?sfvrsn=2d144a9a_2

[5] FRAC (2020) http://www.frac.info/working-group/sdhi-fungicides/general-userecommendations/ grapes-pomefruit-vegetables-and-small-fruits

[6] Amiri, A., Heath, M. and Peres, N.A. (2014) Resistance to Fluopyram, Fluxapyrosad, and Penthiopyrad in Botrytis cinerea from Strawberry. Plant Disease, 98, 532-539. https://doi.org/10.1094/PDIS-07-13-0753-RE

[7] De Miccolis, A., Angelini, R.M., Habib, W., Rotolo, C., Pollastro, S. and Faretra F. (2010) Selection, Characterization and Genetic Analysis of Laboratory Mutans of Botryotinia fuckeliana (Botrytis cinerea) Resistant to the Fungicide Boscalid. European Journal of Plant Pathology, 128, 185-199. https://doi.org/10.1007/s10658-010-9643-8

[8] Bardas, G.A., Veloukos, T., Koutita, Q. and Karaoglandis, G.S. (2010) Multiple Resistance of Botrytis cinerea from Kiwifruit to SDHIs and QoIs and Fungicides of Other Groups. Pest Management Science, 66, 967-973. https://doi.org/10.1002/ps.1968

[9] Gudmestad, N.C., Arabiat, S., Miller, J.S. and Pasche, J.S. (2013) Prevalence and Impact of SDHI Fungicide Resistance in Alternaria solani. Plant Disease, 97, 952-960. https://doi.org/10.1094/PDIS-12-12-1176-RE

[10] Myamotoa, T., Ishii, G., Stammler, A., Koch, T. and Ogawara, M. (2009) Distribution and Molecular Characterization of Corynespora cassiicola Isolates Resistant to Boscalid. Plant Pathology, 59, 873-881. https://doi.org/10.1111/j.1365-3059.2010.02321.x

[11] Toffolatti, S., Venturini, G. and Bianco, P.A. (2016) First Report of SDHI Resistant 
Strains of Venturia inaequalis from Commercial Orchards in Northern Italy. Plant Disease-Diseases Notes, 100, 2324.

https://doi.org/10.1094/PDIS-03-16-0361-PDN

[12] Brunelli, A., Collina, M. and Fiaccadori, R. (2018) Attività preventiva e curativa di fungicidi SDHI nei confronti di Venturia inaequalis. Atti Giornate Fitopatologiche, 2, 457-462.

[13] Battistini, G., Finestrelli, A., Brunelli, A. and Fiaccadori, R. (2016) Valutazione dell'attivita curativa di vecchi e recenti Fungicidi su Venturia inaequalis. Atti Giornate Fitopatologiche, 2, 345-352.

[14] Bugiani, R., Pradolesi, G. and Donati, G. (2016) Valutazione dei fungicidi ISDH nel contenimento della ticchiolatura del melo (Venturia inaequalis). Atti Giornate Fitopatologiche, II, 353-360.

[15] Cesari, A., Fiaccadori, R. and Brandolini, V. (1985) Résistance à la dodine chez Venturia inaequalis dans les vergers de pommiers de l'Italie septentrionale. EPPO Bulletin, 15, 473-476. https://doi.org/10.1111/j.1365-2338.1985.tb00257.x

[16] Fiaccadori, R., Collina, M. and Brunelli, A. (2013) Reduced Sensitivity of Venturia inaequalis to Strobilurins and Anilinopyrimidines in Italy. Integrated Protection of Fruit Crops IOBC-WPRS Bulletin, 91, 345-350.

[17] Fiaccadori, R. (2017) Researches on Methodologies to Verify in Field Sensitivity of Venturia inaequalis to Difenoconazole and First Indications of a Survey in Italy. American Journal of Plant Sciences, 8, 2056-2068. https://doi.org/10.4236/ajps.2017.89138

[18] Hu, M., Fernandez-Ortuno, D. and Schnabel, G. (2016) Monitoring Resistance in SDHI Fungicides in Botrtis cinerea from Strawberry Fields. Plant Disease, 100, 959-965. https://doi.org/10.1094/PDIS-10-15-1210-RE

[19] Huf, A., Rehfus, A., Teichmann, M., Randall, G.R. and Stammler, G. (2017) Sensitivity of Venturia inaequalis to Fungicides. Proceedings of the 18th International Reinhardsbruun Symposium: Modern Fungicides and Anti Fungal Compounds, vol. VIII, Friedrichroda, 197-198.

[20] Fiaccadori, R. (2018) In Vitro, in Vivo and in Field Sensitivity of Venturia inaequalis to Anilinopyrimidine Fungicides with Different Types of Scab Management and Degree of Control. Open Access Library Journal, 5, 1-13. https://doi.org/10.4236/oalib.1105092 